\title{
UJI TOKSISITAS DAUN DAN BUNGA TAHI KOTOK JINGGA (TAGETES ERECTA) MENGGUNAKAN METODE BSLT (BRINE SHRIMP LETHALITY TEST)
}

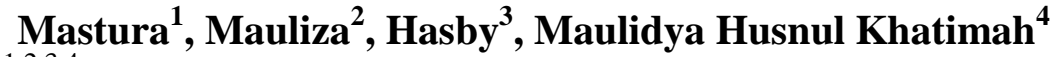 \\ 1,2,3,4 Pendidikan Kimia, Universitas Samudra, Kota Langsa \\ Jln. Kampus Meurandeh, Langsa 24416 \\ *Email: mastura@unsam.ac.id
}

\begin{abstract}
Abstrak
Metode penapisan awal pada pengobatan bahan alam untuk antikanker yang dapat dilakukan adalah dengan uji toksisitas ekstrak tumbuhan. Berdasarkan uji pendahuluan yang dilakukan ekstrak daun dan bunga tahi kotok jingga (Tagetes erecta) memiliki kandungan metabolit sekunder alkaloid, flavonoid dan fenol. Penelitian ini bertujuan untuk mengetahui kandungan metabolit sekunder dan toksisitas ekstrak daun dan bunga tahi kotok jingga (Tagetes erecta) menggunakan metode Brine Shrimp Lethality Test (BSLT). Kandungan toksisitas dibuktikan melalui perhitungan $\mathrm{LC}_{50}$ yang dianalisis dengan regresi linear melalui microsoft office excel. Kandungan metabolit sekunder berupa flavonoid, alkaloid dan fenol dari ekstrak daun dan bunga tahi kotok jingga (Tagetes erecta) dianalisis dengan uji reagen standar. Penelitian uji toksisitas dilakukan 3 kali pengulangan (triplo) dimana setiap pengulangan menggunakan 1 larutan kontrol dan 3 konsentrasi yang masing-masing terdiri atas konsentrasi 1000 ppm, $100 \mathrm{ppm}$ dan $10 \mathrm{ppm}$. Berdasarkan analisis regresi linear nilai $\mathrm{LC}_{50}$ yang diperoleh adalah daun tahi kotok jingga (Tagetes erecta) 58,817 ppm dan bunga tahi kotok jingga (Tagetes erecta) adalah 23,290 ppm. Berdasarkan penelitian yang telah dilakukan diketahui bahwa ekstrak kental daun dan bunga tahi kotok jingga (Tagetes erecta) memiliki kandungan metabolit sekunder alkaloid, flavonoid dan fenol. Selain itu, ekstrak kental daun dan bunga tahi kotok jingga (Tagetes erecta) juga bersifat sangat toksik dan toksik.
\end{abstract}

Kata Kunci: Brine Shrimp Lethality Test (BSLT), tahi kotok jingga (Tagetes erecta), uji toksisitas.

\begin{abstract}
The initial screening method for the treatment of natural ingredients for anticancer that can be done is the toxicity test of plant extracts. Based on preliminary tests conducted, leaf and flower extracts of the tahi kotok jingga (Tagetes erecta) contain secondary metabolites of alkaloids, flavonoids and phenols. This study aims to determine the content of secondary metabolites and the toxicity of leaf and flower extracts of the tahi kotok jingga (Tagetes erecta) using the Brine Shrimp Lethality Test (BSLT) method. Toxicity content was proven by calculating $L C_{50}$ which was analyzed by linear regression through microsoft office excel. The content of secondary metabolites such as flavonoids, alkaloids and phenols of tahi kotok jingga (Tagetes erecta)'s leaf and flower extract were examined with standard reagent tests. The toxicity test was carried out three times where each repetition used 1 control solution and 3 concentrations, each consisting of concentrations of $1000 \mathrm{ppm}, 100 \mathrm{ppm}$ and $10 \mathrm{ppm}$. Based on linear regression analysis of the $L C_{50}$ value obtained Leaves of tahi kotok jingga (Tagetes erecta) is 58.817 ppm and Flowers of Tahi Kotok Jingga (Tagetes erecta) is 23.290 ppm. Based on the research that has been done, it is known that the thick extract of the leaves and flowers of the tahi kotok jingga (Tagetes erecta) contains secondary metabolites of alkaloids, flavonoids and phenols. In addition, the thick extract of the leaves and flowers of the tahi kotok jingga (Tagetes erecta) is also very toxic and toxic.
\end{abstract}

Keywords: Brine Shrimp Lethality Test (BSLT), tahi kotok jingga (Tagetes erecta), toxicity test. 


\section{PENDAHULUAN}

Kanker merupakan penyakit kronis yang dipengaruhi oleh banyak faktor. Teknologi di bidang kesehatan yang terus berkembang telah berhasil menemukan teknologi dan obat-obatan anti kanker. Faktor biaya yang mahal dan efek samping yang ditimbulkan kerap kali menjadi kendala sehingga sebagian besar masyarakat lebih memilih pengobatan tradisional.

Salah satu metode pengujian yang dilakukan dengan tujuan penapisan untuk aktivitas antikanker dalam tumbuhan bahan alam adalah menganalisis kadar toksisitas dalam ekstrak tanaman tersebut. Toksisitas adalah kemampuan suatu zat untuk menimbulkan kerusakan pada organisme hidup yakni seperti menyebabkan gangguan fungsional, fisiologis (struktural), ataupun biokimiawi yang dapat berakibat terganggunya kondisi tubuh secara umum akibat kesakitan yang disebabkan oleh suatu zat. Definisi lain dari toksisitas adalah kapasitas suatu zat untuk dapat menimbulkan efek bahaya Priyanto (2009). Jika ekstrak tanaman memiliki kadar toksisitas yang tinggi maka tanaman tersebut berpotensi sebagai antikanker.

Menurut Rafiqah, dkk., (2019) keberadaan senyawa alkaloid dan flavonoid dalam tumbuhan memiliki hubungan dengan senyawa antikanker. Tumbuhan yang memiliki kandungan alkaloid dan flavonoid mampu bertindak sebagai toksik terhadap sel kanker dalam tubuh manusia sehingga dapat dimanfaatkan sebagai senyawa antikanker.

Salah satu metode yang dapat digunakan pada uji toksisitas adalah metode BSLT (Brine Shrimp Lethality Test). Uji BSLT merupakan metode yang banyak digunakan untuk menganalisis senyawa anti kanker baru yang berasal dari tanaman. Metode ini menggunakan larva Artemia salina L. sebagai hewan coba Hasanah dan Anggita (2018).

Pengujian menggunakan BSLT diterapkan dengan menentukan nilai Lethal Concentration $50 \%\left(\mathrm{LC}_{50}\right)$ setelah perlakuan 24 jam. Nilai $\mathrm{LC}_{50}$ merupakan angka yang menunjukkan konsentrasi suatu bahan penyebab kematian sebesar 50\% dari jumlah hewan coba Wibowo, dkk., (2013). Tingkat ketoksikan suatu senyawa dapat dilihat berdasarkan nilai $\mathrm{LC}_{50}$ yang diperoleh, dimana dapat dilihat pada tabel 1 .

Tabel 1. Kategori Toksisitas Berdasarkan $\mathrm{LC}_{50}$

\begin{tabular}{|c|c|}
\hline Kategori & LC $_{\mathbf{5 0}}$ (ppm) \\
\hline Sangat Toksik & $<30$ \\
\hline Toksik & $30-1000$ \\
\hline Tidak Toksik & $>1000$ \\
\hline
\end{tabular}

(Sumber: Meyer, 1982)

Tanaman tahi kotok jingga (Tagetes erecta) dikenal sebagai tanaman herbal di kalangan masyarakat karena memiliki beragam khasiat. Tanaman ini sering digunakan sebagai obat dalam penyembuhan radang kulit bernanah (pyodermi), infeksi saluran nafas bagian atas, pembengkakan payudara (mastitis) dan sebagainya Yulia dan Ranova (2018).

Uji pendahuluan yang telah dilakukan menunjukkan tanaman tahi kotok jingga (Tagetes erecta) memiliki kandungan metabolit sekunder berupa alkaloid, flavonoid dan fenol, sehingga diduga berpotensi sebagai senyawa antikanker. Berdasarkan hal ini perlu dilakukan penelitian mengenai uji toksisitas daun dan bunga tahi kotok jingga (Tagetes erecta) untuk mengetahui tingkat ketoksikan tanaman ini serta kandungan metabolit sekunder yang terkandung di dalamnya.

\section{METODOLOGI PENELITIAN}

\section{Persiapan Sampel}

Sampel daun dan bunga tahi kotok jingga (Tagetes erecta) dicuci bersih, ditiriskan, dan diangin-anginkan di dalam ruangan hingga kandungan airnya habis. 
Proses menghilangkan kadar air di dalam daun ini penting agar sampel tidak berjamur. Kemudian daun yang sudah kering dirajang kecil-kecil dan diblender hingga halus.

\section{Persiapan Larva Udang Artemia salina Leach}

Penetasan dilakukan dengan cara merendam $1 \mathrm{~g}$ telur Artemia salina L.dalam air laut sebanyak $2 \mathrm{~L}$ dan diberi penerangan dengan lampu pijar 40-60 watt serta di aerasi selama 48 jam Arter, dkk., (2013).

\section{Ekstraksi}

Ditimbang sebanyak 200 g serbuk simplisia yang kemudian ditambahkan dengan pelarut etanol 76\% $2000 \mathrm{ml}$ (1:10) kemudian wadah ditutup dengan alumunium foil dan direndam selama 48 jam. Setelah selesai disaring menggunakan kain batis untuk memisahkan filtrat dengan residunya Kusuma, dkk., (2015).

\section{Skrining Fitokimia}

a. Uji Alkaloid

Serbuk simplisia ditimbang $0,5 \mathrm{~g}$ kemudian ditambahkan $1 \mathrm{~mL} \mathrm{HCl} 2 \mathrm{~N}$ dan 9 $\mathrm{ml}$ aquades, dipanaskan di atas penangas air selama dua menit, dinginkan dan saring, filtrat yang didapat digunakan untuk pengujian. Diambil 10 tetes filtrat dimasukkan ke dalam tabung reaksi ditambahkan 2 tetes pereaksi mayer dan terbentuk endapan putih atau kuning. Selanjutnya diambil 10 tetes filtrat dimasukkan kedalam tabung reaksi ditambahkan 2 tetes pereaksi wagner sehingga terbentuk endapan merah. Kemudian 10 tetes filtrat dimasukkan kedalam tabung reaksi ditambahkan 2 tetes pereaksi dragendrof dan terbentuk endapan jingga sampai merah coklat. Bila sedikitnya 2 dari 3 pereaksi menghasilkan endapan yang sama maka positif mengandung alkaloid Sentat (2015).

b. Uji Flavonoid

Sebanyak 10 g serbuk simplisia ditambahkan dengan $100 \mathrm{ml}$ air panas. Campuran kemudian didihkan selama lebih kurang 5 menit, kemudian disaring ketika panas. Sebanyak $5 \mathrm{ml}$ filtrat yang diperoleh, ditambahkan 0,1 g serbuk $\mathrm{Mg}, 1 \mathrm{ml} \mathrm{HCl}$ pekat dan $2 \mathrm{ml}$ amil alkohol, dikocok dan dibiarkan memisah. Flavonoid positif jika terjadi warna merah, kuning, jingga pada lapisan amil alkohol Marjoni (2016).

c. Uji Fenol

Uji fenol dilakukan dengan mereaksikan $1 \mathrm{~mL}$ ekstrak dengan $\mathrm{FeCl}_{3} 1 \%$. Jika terbentuk warna hijau, merah, ungu, biru tua, biru, biru kehitaman, atau hijau kehitaman, maka ekstrak sampel tersebut diketahui positif mengandung senyawa metabolit sekunder yaitu senyawa fenol Wardhani, dkk., (2018).

\section{Pembuatan Larutan Sampel}

a. Pembuatan Larutan Sampel Konsentrasi 2000, 200 dan 20 ppm

Larutan ekstrak 2000 ppm dibuat dengan menimbang sebanyak $40 \mathrm{mg}$ ekstrak kemudian dilarutkan dalam $20 \mathrm{~mL}$ air laut. Untuk ekstrak yang sukar larut, dapat ditambahkan DMSO $1 \%$ (5 tetes) untuk meningkatkan kelarutan. Konsentrasi 200 ppm dibuat dengan memipet $2 \mathrm{~mL}$ larutan ekstrak 2000 ppm dan ditambahkan air laut sampai $20 \mathrm{~mL}$. Konsentrasi $20 \mathrm{ppm}$ dibuat dengan memipet $2 \mathrm{~mL}$ larutan konsentrasi 200 ppm dan ditambahkan air laut sampai 20 mL Rafiqah, dkk., (2019).

b. Pembuatan Larutan Sampel Konsentrasi 1000, 100 dan 10 ppm

Larutan sampel lainnya yang diperlukan adalah larutan dengan konsentrasi 1000 ppm, 100 ppm, dan 10 ppm untuk uji toksisitas. Larutan sampel $1000 \mathrm{ppm}$ dibuat dengan cara memipet $5 \mathrm{~mL}$ larutan ekstrak 2000 ppm dan ditambahkan air laut $5 \mathrm{ml}$. Konsentrasi 100 ppm dibuat dengan cara memipet larutan ekstrak 200 ppm sebanyak 5 $\mathrm{mL}$ dan ditambahkan air laut $5 \mathrm{~mL}$. Larutan sampel $10 \mathrm{ppm}$ dibuat dengan cara memasukkan larutan ekstrak 20 ppm dan ditambahkan $5 \mathrm{~mL}$ air laut Rafiqah, dkk., (2019). 


\section{Uji Toksisitas}

Uji toksisitas dilakukan dengan memasukkan 15 ekor larva udang Artemia salina L. yang berumur 48 jam ke dalam botol yang telah berisi larutan ekstrak dan air laut. Untuk setiap konsentrasi dilakukan 3 kali pengulangan (triplo). Sebagai kontrol adalah air laut yang tidak diberi ekstrak sampel. Botol percobaan disimpan di bawah pencahayaan lampu tl. Pengamatan dilakukan setelah 24 jam. Jumlah larva udang yang mati dicatat kemudian dihitung persentase kematian nya. Data yang diperoleh diolah dengan menggunakan analisis probit Rafiqah, dkk., (2019).

$\%$ Kematian larva $=\frac{\text { Iumlah larwa udangyang mati }}{\text { furilah lavva awal }} \times 100 \%$

Setelah didapatkan persen kematian larva udang, selanjutnya dicari nilai probit dari tiap kelompok hewan uji melalui tabel probit. Selanjutnya ditentukan persamaan garis lurus $\mathrm{Y}=\mathrm{mX}+\mathrm{b}$ melalui microsoft office excel. Nilai $\mathrm{LC}_{50}$ diperoleh dengan mencari antilog dari nilai X Juniarti, dkk., (2009).

\section{HASIL DAN PEMBAHASAN}

\section{Hasil Ekstraksi}

Ekstrak daun dan bunga tahi kotok jingga (Tagetes erecta) telah diuapkan pelarut etanolnya menggunakan rotary evaporator sehingga diperoleh ekstrak kental. Hasil ekstrak yang diperoleh dari masing-masing sampel dapat dilihat pada tabel 2.

Tabel 2. Hasil Ekstraksi daun dan bunga tahi kotok jingga (Tagetes erecta)

\begin{tabular}{|l|c|c|c|}
\hline Nama Sampel & \multirow{2}{*}{$\begin{array}{c}\text { Bobot } \\
\text { Kering }\end{array}$} & \multicolumn{2}{|c|}{ Ekstrak Kental } \\
\cline { 3 - 4 } & & Bobot & Warna \\
\hline $\begin{array}{l}\text { daun tahi kotok } \\
\text { jingga (Tagetes } \\
\text { erecta) }\end{array}$ & $96 \mathrm{~g}$ & $16 \mathrm{~g}$ & $\begin{array}{c}\text { Hijau } \\
\text { Kehitam } \\
\text { an }\end{array}$ \\
\hline $\begin{array}{l}\text { bunga tahi } \\
\text { kotok jingga } \\
\text { (Tagetes erecta) }\end{array}$ & $97 \mathrm{~g}$ & $17 \mathrm{~g}$ & $\begin{array}{c}\text { Coklat } \\
\text { Pekat }\end{array}$ \\
\hline
\end{tabular}

\section{Hasil Skrining Fitokimia daun dan bunga tahi kotok jingga (Tagetes erecta)}

Skrining fitokimia dilakukan untuk melihat kandungan metabolit sekunder yang terdapat di dalam sampel. Hasil skrining fitokimia daun dan bunga tahi kotok jingga (Tagetes erecta) dapat dilihat pada tabel 3 .

Tabel 3. Hasil Skrining Fitokimia Daun dan Bunga Tahi Kotok Jingga (Tagetes erecta)

\begin{tabular}{|c|c|c|c|c|}
\hline $\begin{array}{l}\text { Nama } \\
\text { Sampel }\end{array}$ & $\begin{array}{l}\text { Kandun } \\
\text { gan } \\
\text { Kimia }\end{array}$ & Pereaksi & Hasil & Ket \\
\hline \multirow{5}{*}{$\begin{array}{c}\text { Daun } \\
\text { tahi } \\
\text { kotok } \\
\text { jingga } \\
\text { (Tagetes } \\
\text { erecta) }\end{array}$} & & Mayer & $\begin{array}{c}\text { Hijau } \\
\text { Kecok- } \\
\text { latan }\end{array}$ & - \\
\hline & Alkaloid & Wagner & $\begin{array}{c}\text { Endap- } \\
\text { an } \\
\text { Merah }\end{array}$ & + \\
\hline & & $\begin{array}{l}\text { Dragend- } \\
\text { rof }\end{array}$ & $\begin{array}{c}\text { Hijau } \\
\text { Kecok- } \\
\text { latan }\end{array}$ & - \\
\hline & $\begin{array}{c}\text { Flavono- } \\
\text { id }\end{array}$ & $\begin{array}{c}\text { Logam } \\
\mathrm{Mg}+ \\
\mathrm{HCl}\end{array}$ & Jingga & + \\
\hline & Fenol & $\mathrm{FeCl}_{3} 5 \%$ & $\begin{array}{l}\text { Hijau } \\
\text { Kehit- } \\
\text { aman }\end{array}$ & + \\
\hline \multirow{5}{*}{$\begin{array}{c}\text { Bunga } \\
\text { tahi } \\
\text { kotok } \\
\text { jingga } \\
\text { (Tagetes } \\
\text { erecta) }\end{array}$} & & Mayer & $\begin{array}{l}\text { Coklat } \\
\text { Muda }\end{array}$ & - \\
\hline & Alkaloid & Wagner & $\begin{array}{c}\text { Endap- } \\
\text { an } \\
\text { Merah }\end{array}$ & + \\
\hline & & $\begin{array}{l}\text { Dragend- } \\
\text { rof }\end{array}$ & $\begin{array}{c}\text { Endap- } \\
\text { an } \\
\text { Jingga }\end{array}$ & + \\
\hline & $\begin{array}{c}\text { Flavono- } \\
\text { id }\end{array}$ & $\begin{array}{c}\text { Logam } \\
\mathrm{Mg}+ \\
\mathrm{HCl}\end{array}$ & Jingga & + \\
\hline & Fenol & $\mathrm{FeCl}_{3} 5 \%$ & $\begin{array}{l}\text { Hijau } \\
\text { Kehit- } \\
\text { aman }\end{array}$ & + \\
\hline
\end{tabular}

Keterangan:

(+) Terdapat kandungan metabolit sekunder

(-) Tidak terdapat kandungan metabolit sekunder 
Berdasarkan hasil yang ditampilkan pada tabel 3 diketahui daun dan bunga tahi kotok jingga (Tagetes erecta) memiliki kandungan alkaloid, flavonoid dan fenol.

Keradaan senyawa alkaloid dan flavonoid dalam ekstrak tumbuhan berhubungan dengan tingkatan kematian larva Artemia salina L karena senyawasenyawa ini akan bertindak sebagai stomatch poisoning (racun perut). Ketika larva Artemia salina L. berada dalam larutan yang mengandung senyawa-senyawa tersebut, maka senyawa akan masuk dan merusak alat pencernaan larva. Senyawa alkaloid dan flavonoid ini akan mengakibatkan larva kehilangan stimulus rasa sehingga tidak mampu mengidentifikasi makanan yang ada disekitarnya. Oleh karena itu, larva akan mati akibat kelaparan dan ekstrak dianggap memiliki kemampuan untuk bersifat toksik Rafiqah, dkk., (2019).

\section{Hasil Uji Toksisitas tahi kotok jingga} (Tagetes erecta) dengan Metode BSLT

Tingkat ketoksikan suatu senyawa dapat dilihat melalui persentase kematian larva Artemia salina L. yang dimasukkan ke dalam larutan sampel. Hasil uji toksisitas esktrak daun dan bunga tahi kotok jingga (Tagetes erecta) dengan metode BSLT akan ditampilkan pada tabel 4.

Tabel 4. Pengaruh berbagai konsentrasi ekstrak daun dan bunga tahi kotok jingga (Tagetes erecta) terhadap larva Artemia salina L.

\begin{tabular}{|c|c|c|c|c|c|}
\hline \multirow{3}{*}{$\begin{array}{c}\text { Jenis } \\
\text { Ekstrak }\end{array}$} & \multirow{3}{*}{$\begin{array}{c}\text { Ulang- } \\
\text { an }\end{array}$} & \multirow{2}{*}{\multicolumn{3}{|c|}{$\begin{array}{c}\text { Angka Kematian } \\
\text { Larva Artemia } \\
\text { dari } 15 \text { larva } \\
\begin{array}{c}\text { Konsentrasi ekstrak } \\
\text { (ppm) }\end{array}\end{array}$}} & \multirow{3}{*}{$\begin{array}{c}\text { Kon- } \\
\text { trol }\end{array}$} \\
\hline & & & & & \\
\hline & & $\begin{array}{l}1000 \\
\text { ppm }\end{array}$ & $\begin{array}{c}100 \\
\text { ppm }\end{array}$ & $\begin{array}{c}10 \\
\text { ppm }\end{array}$ & \\
\hline \multirow{5}{*}{$\begin{array}{l}\text { Daun tahi } \\
\text { kotok } \\
\text { jingga } \\
\text { (Tagetes } \\
\text { erecta) }\end{array}$} & 1 & 13 & 7 & 4 & 0 \\
\hline & 2 & 11 & 7 & 5 & 0 \\
\hline & 3 & 9 & 8 & 5 & 0 \\
\hline & Total & 33 & 22 & 14 & $\mathbf{0}$ \\
\hline & $\begin{array}{c}\% \\
\text { Kema- } \\
\text { tian }\end{array}$ & 73,3 & 48,8 & 31,1 & 0 \\
\hline \multirow{2}{*}{$\begin{array}{c}\text { Bunga } \\
\text { tahi kotok }\end{array}$} & 1 & 15 & 7 & 6 & 0 \\
\hline & 2 & 12 & 8 & 4 & 0 \\
\hline
\end{tabular}

\begin{tabular}{|c|c|c|c|c|c|}
\hline $\begin{array}{c}\text { jingga } \\
\text { (Tagetes }\end{array}$ & 3 & 14 & 8 & 6 & 0 \\
\cline { 2 - 6 } erecta) & Total & $\mathbf{4 1}$ & $\mathbf{2 3}$ & $\mathbf{1 6}$ & $\mathbf{0}$ \\
\cline { 2 - 6 } & $\begin{array}{c}\mathbf{\%} \\
\text { Kema- } \\
\text { tian }\end{array}$ & $\mathbf{9 1 , 1}$ & $\mathbf{5 1 , 1}$ & $\mathbf{3 5 , 5}$ & $\mathbf{0}$ \\
\hline
\end{tabular}

Persentase kematian yang diperoleh dapat ditampilkan dalam bentuk grafik. Grafik dibuat berdasarkan perbandingan persentase kematian larva Artemia salina L. terhadap konsentrasi ekstrak dari seluruh sampel penelitian. Grafik masing-masing sampel ditampilkan pada gambar 1 dan 2 .

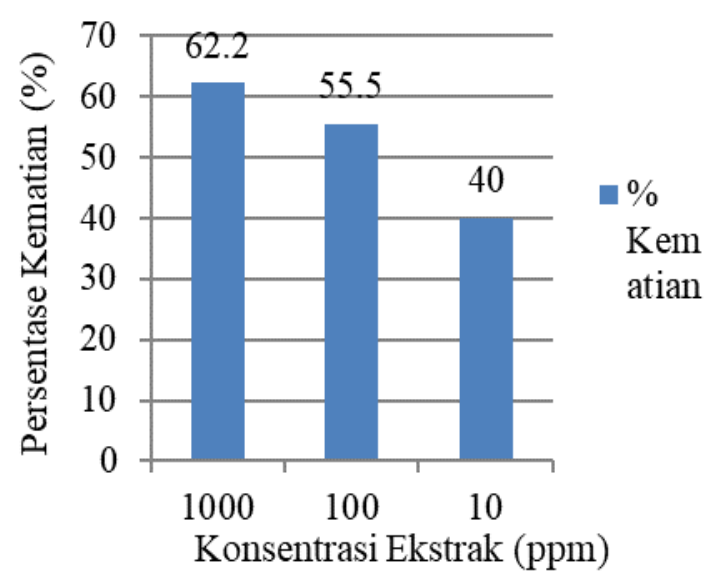

Gambar 1.Grafik Pengaruh Konsentrasi Ekstrak daun tahi kotok jingga (Tagetes erecta) Terhadap Kematian Larva Artemia salina $\mathrm{L}$.

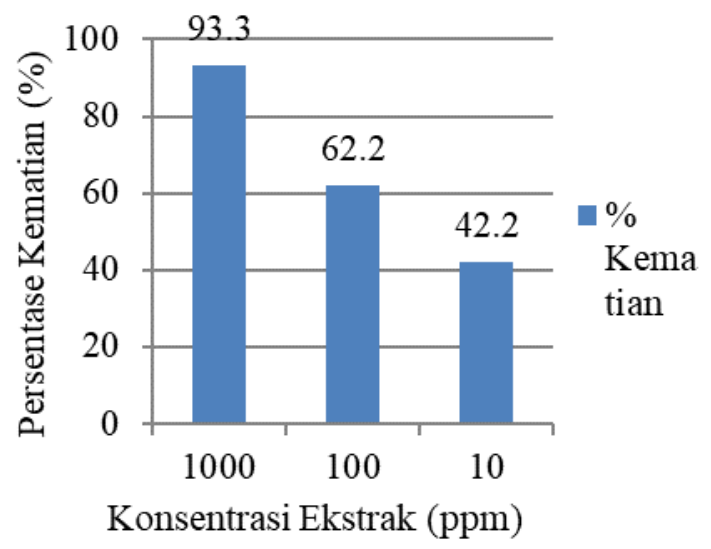

Gambar 2. Grafik Pengaruh Konsentrasi Ekstrak bunga tahi kotok jingga (Tagetes erecta) Terhadap Kematian Larva Artemia salina $\mathrm{L}$. 


\begin{tabular}{|c|c|c|c|c|c|c|}
\hline $\begin{array}{c}\text { Kons } \\
\text { entra } \\
\text { si }\end{array}$ & $\begin{array}{c}\text { Log } \\
\text { Konse } \\
\text { ntrasi } \\
(\mathbf{X})\end{array}$ & $\begin{array}{c}\text { \% } \\
\text { Ke } \\
\text { mati } \\
\text { an }\end{array}$ & $\begin{array}{c}\text { Probit } \\
(\mathbf{Y})\end{array}$ & $\mathbf{X}^{\mathbf{2}}$ & $\mathbf{Y}^{\mathbf{2}}$ & $\mathbf{X Y}$ \\
\hline 1000 & 3 & 62,2 & 5,3107 & 9 & 28,2035 & $\begin{array}{c}15,932 \\
1\end{array}$ \\
\hline 100 & 2 & 55,5 & 5,1383 & 4 & 26,4021 & $\begin{array}{c}10,276 \\
6\end{array}$ \\
\hline 10 & 1 & 40 & 4,7467 & 1 & 22,5311 & 4,7467 \\
\hline $\begin{array}{c}\text { Jumla } \\
\text { h }\left(\sum\right)\end{array}$ & $\mathbf{6}$ & $\begin{array}{c}\mathbf{1 5 7}, \\
\mathbf{7}\end{array}$ & $\begin{array}{c}\mathbf{1 5 , 1 9 5} \\
\mathbf{7}\end{array}$ & $\mathbf{1 4}$ & $\mathbf{7 7 , 1 3 6 7}$ & $\begin{array}{c}\mathbf{3 0 , 9 5 5} \\
\mathbf{4}\end{array}$ \\
\hline
\end{tabular}

Berdasarkan gambar 1 dapat dilihat bahwa larva Artemia salina L. sangat susah bertahan hidup pada ekstrak daun tahi kotok jingga (Tagetes erecta) konsentrasi 1000 ppm. Dari jumlah total 15 ekor larva diperoleh persentase kematian sebanyak 62,2\% pada konsentrasi 1000 ppm dimana pada konsentrasi 100 ppm dan 10 ppm diperoleh persentase kematian masingmasing larva sebanyak $55,5 \%$ dan $40 \%$. Hal ini menunjukkan bahwa semakin besar konsentrasi ekstrak maka semakin besar pula tingkat kematian larva.

Pada gambar 2 ditampilkan grafik hubungan konsentrasi ekstrak bunga tahi kotok jingga (Tagetes erecta) dengan persentase kematian larva Artemia salina L. berdasarkan gambar tersebut dapat dilihat bahwa persen kematian tertinggi berada pada konsentrasi ekstrak 1000 ppm yang memperoleh 93,3\% kematian dan persen kematian terendah berada pada konsentrasi $10 \mathrm{ppm}$ yaitu $42,2 \%$. Dalam hal ini dapat disimpulkan bahwa ekstrak yang memiliki tingkat toksisitas paling tinggi adalah ekstrak yang memiliki konsentrasi paling tinggi. Hal ini sesuai dengan penelitian yang dilakukan oleh Putri, dkk., (2013) yang menyatakan semakin tinggi konsentrasi ekstrak maka sifat toksiknya akan semakin tinggi.

\section{Hasil Penetapan $\mathrm{LC}_{\mathbf{5 0}}$}

1) Penetapan $\mathrm{LC}_{50}$ Daun Tahi Kotok Jingga (Tagetes erecta)

$\mathrm{LC}_{50}$ dapat diketahui dengan membuat grafik persamaan garis lurus $\mathrm{y}=$ $\mathrm{mX}+\mathrm{b}$ di microsoft office excel. Diperlukan beberapa nilai yang saling berhubungan untuk membuat grafik, agar lebih mudah dalam pengerjaan maka nilai-nilai tersebut akan ditampilkan dalam tabel 5.

Tabel 5. Penetapan $\mathrm{LC}_{50}$ Daun Tahi Kotok Jingga (Tagetes erecta) dengan Microsoft Office Excel

Berdasarkan tabel 5 diperoleh grafik persamaan garis lurus terhadap ekstrak daun tahi kotok jingga (Tagetes erecta). Grafik akan ditampilkan pada gambar 3.

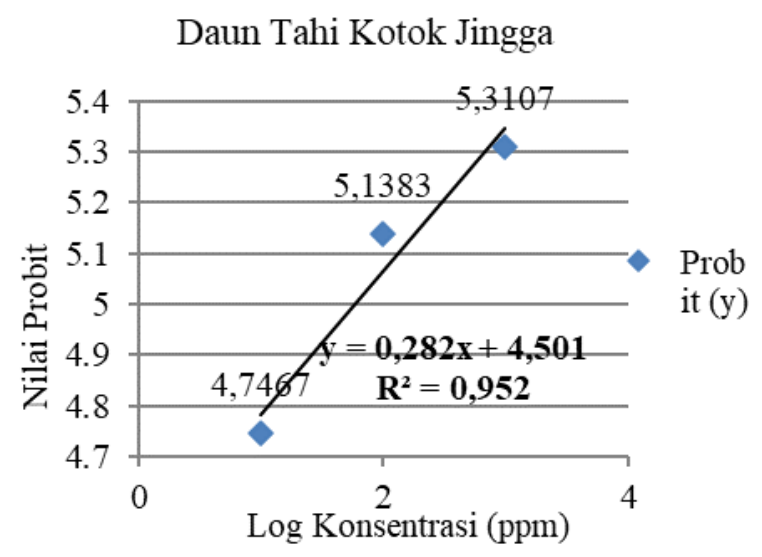

Gambar 3. Grafik Regresi Linear Log Konsentrasi Ekstrak Daun Tahi Kotok Jingga

(Tagetes erecta) Terhadap Nilai Probit

Berdasarkan gambar 3 diperoleh persamaan garis lurus $\mathrm{Y}=0,282 \mathrm{X}+5,501$. Dari persamaan tersebut dicari antilog dari nilai $\mathrm{X}$ (log konsentrasi) sehingga didapat nilai $\mathrm{LC}_{50}$ daun tahi kotok jingga sebesar 58,817 ppm. Menurut Meyer (1982) suatu senyawa bersifat toksik apabila memiliki nilai $\mathrm{LC}_{50}$ dibawah $1000 \mathrm{ppm}$. Berdasarkan hal ini maka disimpulkan bahwa ekstrak daun tahi kotok jingga (Tagetes erecta) bersifat toksik.

2) Penetapan $\mathrm{LC}_{50}$ Bunga Tahi Kotok Jingga (Tagetes erecta)

Grafik persamaan garis lurus $\mathrm{y}=\mathrm{mX}$ $+\mathrm{b}$ untuk menentukan nilai $\mathrm{LC}_{50}$ dari bunga tahi kotok jingga (Tagetes erecta) dihitung menggunakan microsoft office excel. Untuk memenuhi angka-angka yang dibutuhkan pada rumus microsoft office excel perlu dibuat tabel yang mencantumkan angka- 
angka tersebut, berikut ditampilkan dalam tabel 6.

Tabel 6. Penetapan $\mathrm{LC}_{50}$ Bunga Tahi Kotok Jingga (Tagetes erecta) dengan Microsoft Office Excel

\begin{tabular}{|c|c|c|c|c|c|c|}
\hline $\begin{array}{c}\text { Kons } \\
\text { entra } \\
\text { si }\end{array}$ & $\begin{array}{c}\text { Log } \\
\text { Kon } \\
\text { sent } \\
\text { rasi } \\
(\mathbf{X})\end{array}$ & $\begin{array}{c}\text { Kema } \\
\text { tian }\end{array}$ & $\begin{array}{c}\text { Probit } \\
(\mathbf{Y})\end{array}$ & $\mathbf{X}^{\mathbf{2}}$ & $\mathbf{Y}^{\mathbf{2}}$ & $\mathbf{X Y}$ \\
\hline 1000 & 3 & 93,3 & 6,4985 & 9 & 42,2305 & 19,4955 \\
\hline 100 & 2 & 62,2 & 5,3107 & 4 & 28,2035 & 10,6214 \\
\hline 10 & 1 & 42,2 & 4,8032 & 1 & 23,0707 & 4,8032 \\
\hline $\begin{array}{c}\text { Jumla } \\
\text { h }\left(\sum\right)\end{array}$ & $\mathbf{6}$ & $\mathbf{1 9 7 , 7}$ & $\begin{array}{c}\mathbf{1 6 , 6 1 2} \\
\mathbf{4}\end{array}$ & $\mathbf{1 4}$ & $\mathbf{9 3 , 5 0 4 7}$ & $\mathbf{3 4 , 9 2 0 1}$ \\
\hline
\end{tabular}

Berdasarkan tabel 6 diperoleh grafik persamaan garis lurus terhadap ekstrak daun tahi kotok jingga (Tagetes erecta). Grafik akan ditampilkan pada gambar 4 .

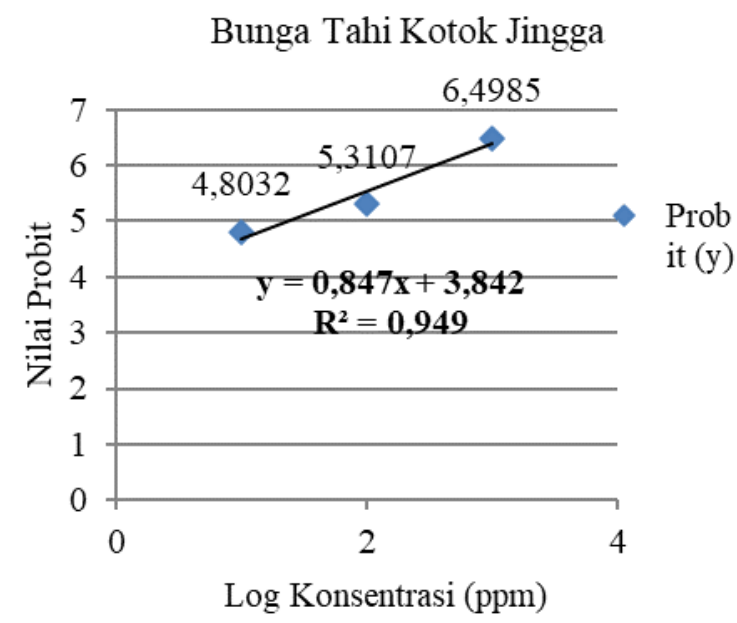

Gambar 4. Grafik Regresi Linear Log Konsentrasi Ekstrak Bunga Tahi Kotok Jingga (Tagetes erecta) Terhadap Nilai Probit

Gambar 4 menunjukkan grafik persamaan garis lurus $\mathrm{y}=0,847 \mathrm{x}+3,842$ yang merupakan hubungan antara nilai probit dengan log konsentrasi. Berdasarkan persamaan tersebut diperoleh nilai $\mathrm{LC}_{50}$ sebesar 23,290 ppm. Berdasarkan Meyer (1982) bunga tahi kotok jingga (Tagetes erecta) bersifat sangat toksik karena memiliki nilai $\mathrm{LC}_{50}<30 \mathrm{ppm}$.

\section{KESIMPULAN}

Daun dan bunga tahi kotok jingga (Tagetes erecta) memiliki kandungan metabolit sekunder berupa alkaloid, flavonoid dan fenol. Daun tahi kotok jingga bersifat toksik dengan nilai $\mathrm{LC}_{50} 58,817$ ppm sedangkan bunga tahi kotok jingga (Tagetes erecta) bersifat sangat toksik dengan nilai $\mathrm{LC}_{50} 3,290$ ppm.

\section{DAFTAR PUSTAKA}

Arter, D.M., Harry, S.J., Koleangana dan Max, R.J.R. 2013. "Uji Toksisitas Dengan Metode BSLT dan Analisis Kandungan Fitokimia Ekstrak Daun Soyogik (Saurauia bracteosa DC) Dengan Metode Soxhletasi", Jurnal MIPA Unsrat Online. Vol. 2, No.2: 115-118, 20 Oktober 2013.

Hasanah, N. dan Anggita, D. 2018. "Skrining Fitokimia dan Uji Toksisitas dari Ekstrak Bunga Kertas (Bougenvillea spectabilis Wild)". Sainstech Farma. Vol 11, No. 2: 21-24, Juli 2018.

Juniarti, Osmeli, D. dan Yuhernita. 2009. "Kandungan Senyawa Kimia, Uji Toksisitas (Brine Shrimp Lethality Test) dan Antioksidan (1,1Dyphenyl-2-Pikrilhydrazyl) dari Ekstrak Daun Saga (Abrus precatorius Huds)", Makara Journal of Sains. Vol. 13, No.1: 50-54, April 2009.

Kusuma, I.J.D., Prasetyorini dan Wardatun, S. 2015. "Toksisitas Ekstrak Daun Kenikir (Cosmos Caudatus Kunth) dengan Perbedaan Metode Dan Jenis Pelarut Berbeda", Jurnal Online Mahasiswa (JOM) Bidang Farmasi. Vol. 1, No. 1:1-9, Maret 2015. 
Marjoni, R. 2016. Dasar-dasar Fitokimia. Jakarta Timur: CV. Transinfo Media.

Meyer, BN, NR. 1982. Brine Shrimp Lehality A Convenient General Bioassay for Active Plant Constituent. Departement of Medical Chemistry and Pharmakognnocy, School of Pharmacy and Pharmacal Science and Cell Culture Libratory, Perdue Cancer Center. West Lavayette: USA.

Priyanto. 2009. TOKSIKOLOGI: Mekanisme, Terapi Antidotum, Dan Penilaian Resiko. Depok: Lembaga Studi Dan Konsultasi Farmakologi Indonesia (Lenskofi).

Rafiqah, Mastura, dan Hasibuan, M.P. 2019. "Uji Toksisitas Fraksi Etanol Tanaman Obat Yang Digunakan Masyarakat Menggunakan Metode Brine Shrimp Lethality Test", KATALIS: Jurnal Pendidikan Kimia dan Ilmu Kimia. Vol . 2, No. 1: 1420, Juni 2019.

Sentat, T. dan Permatasari, R. 2015. "Uji Aktivitas Ekstrak Etanol Daun Alpukat (Persa Americana Mill.) Terhadap Penyembuhan Luka Bakar Pada Punggung Mencit Putih Jantan (Mus musculus)", Jurnal Ilmiah Manuntung. Vol. 1, No. 2: 100-106, Januari 2017.

Wardhani, R.R.A.A.K., Akhyar, O. dan Prasiska, E. 2018. "Analisis Skrining Fitokimia, Kadar Total FenolFlavonoid dan Aktivitas Antioksidan Ekstrak Kulit Kayu Tanaman Galam Rawa Gambut (Melaleuca cajuputi roxb)". Al Ulum Sains dan Teknologi. Vol. 4, No. 1: 39-45, November 2018.
Wibowo, S., Suryaningrum, D. dan Utomo, B.S.B. 2013. Artemia Untuk Pakan Ikan Dan Udang. Jakarta: Penebar Swadaya.

Yulia, M. dan Ranova, R. 2018. "Uji Aktivitas Antioksidan Ekstrak Bunga Tahi Kotok (Tagetes Erecta L.) dengan Metode DPPH (1,1-Difenil-2Pikrihidrazil)", SCIENTIA Jurnal Farmasi dan Kesehatan. Vol. 8, No. 1: 98-103, Februari 2018. 